DOI: 10.34015/2523-4552.2019.2.17

Удк 343.3

Хелік В. В., аспірант кафедри управління безпеки, правоохоронної та антикорупційної діяльності Міжрегіональної Академії управління персоналом

\title{
ПОНЯТТЯ ТА ЗМІСТ ПОРУШЕНЬ ПРАВИЛ БЕЗПЕКИ ДОРОЖНЬОГО РУХУ ОСОБАМИ, ЯКІ КЕРУЮТЬ ТРАСПОРТНИМИ ЗАСОБАМИ
}

У статті розкрито поняття та зміст порушень правил дорожнього руху особами, які керують транспортними засобами. 3'ясовано, що запобігання порушенням правил дорожнього руху особами, які керують транспортними засобами, $\epsilon$ актуальною кримінологічною проблемою. Доведено, що законодавство в цій сфері не $\epsilon$ досконалим і завершеним. Сформульовано авторське визначення порушень правил безпеки дорожнього руху особами, які керують транспортними засобами.

Ключові слова: порушення; правила; дорожній рух; транспорт; особа.

В статье раскрыто понятие и содержание нарушений правил дорожного движения лицами; управляющими транспортными средствами. Установлено, что предотвращение нарушений правил дорожного движения лицами, управляющими транспортными средствами, является актуальной криминологической проблемой. Доказано, что законодательство в этой сфере несовершенно. Сформулировано авторское определение нарушений правил безопасности дорожного движения лицами, управляющими транспортными средствами.

Ключевые слова: нарушение; правила; дорожное движение; транспорт; лицо.

Постановка проблеми. У нашій державі рівень смертності та травматизму внаслідок дорожньо-транспортних пригод є одним з найвищих у Європі, а рівень організації безпеки дорожнього руху залишається вкрай низьким, про що у своїх звітах неодноразово наголошували експерти як В003, Світового банку, так і інших міжнародних інституцій.

Згідно з Резолюцією Генеральної асамблеї Організації Об'єднаних Націй «Про підвищення безпеки до- рожнього руху в усьому світі» від 2 березня 2010 року № 64/255, 20112020 роки проголошені Десятиліттям дій з безпеки дорожнього руху. Крім 69 країн-членів, до реалізації вказаної резолюції долучилася й Україна.

Вивчення поняття та змісту порушень правил дорожнього руху або експлуатації транспорту особами, які керують транспортними засобами, засвідчило, що їх суспільна небезпечність хоча і $€$ видом необе- 
режних злочинів, але коли мова йде про людські жертви, то виникає питання $з$ якою формою вини вони були вчинені .

Серед найбільш поширених видів порушень безпеки дорожнього руху вітчизняний вчений І.Г. Богатирьов виділяє такі: перевищення швидкості руху, обгін транспортних засобів, проїзд перехресть, керування транспортним засобом у стані сп'яніння, управління транспортним засобом за наявності несправностей автомобіля. Водночас учений наголошує на тому, що вчинення великої кількості порушень безпеки дорожнього руху пов'язано з поганим станом автомобільних доріг в Україні та процесами, які варто віднести до технічного або природного характеpy $[1$, c. 103$]$.

Поділяючи таку позицію вченого, на нашу думку, варто вести мову про свідоме порушення особою, яка керує транспортним засобом, правил дорожнього руху або експлуатації транспорту, і при цьому створює небезпечну ситуацію на дорозі незалежно від їі покриття або технічного чи природного характеру.

Вбачається, що саме порушення такою особою правил безпеки дорожнього руху має відносно суб'єктивний особистісний чинник, а тому кримінологічна характеристика особи, яка керує транспортним засобом, має буди предметом розгляду поліцейськими при виїзді на місце вчинення порушення правил безпеки дорожнього руху або експлуатації транспорту.

Постановка завдання. Метою статті $є$ вивчення поняття та змісту порушень правил дорожнього руху особами, які керують транспортними засобами.
Аналіз останніх досліджень та публікацій. Теоретичною основою статті стали праці І.Г.Богатирьова, Б. Ю. Бурбело, С. В. Гізімчука, А. П. Головіна, Т. О.Гуржія, О. М. Джужі, О. В. Дудника, А. П. Закалюка, Я. В. Матвійчук, В. А. Мисливого, А. В. Піддубної, К. О. Полтави, В. І. Осадчого, С. I. Саєнко, А. О. Собакарь, М. Л. Шелухіна та ін.

Виклад основного матеріалу. Серед основних причин порушення правил безпеки дорожнього руху або експлуатації транспорту К. О. Полтава за результатами проведення автотехнічної експертизи називає перевищення водіями дозволеної швидкості руху, порушення ними правил маневрування, несподіваний вихід пішоходів на проїзну частину поза пішохідними переходами, грубе ігнорування водіями правил дорожнього руху та ін.

У свою чергу, вчена зауважує, що саме такі чинники, як перевищення швидкості та виїзд на смугу зустрічного руху, найчастіше фіксуються в протоколах про порушення правил безпеки дорожнього руху або експлуатації транспорту та зазвичай визнаються остаточними причинами ДТП під час проведення автотранспортної експертизи [2, с. 185].

Крім зазначених, чинниками, що детермінують скоєння порушення правил безпеки дорожнього руху або експлуатації транспорту, академік А. П. Закалюк вважає такі:

1) керування транспортом після вживання алкогольних напоїв, у хворобливому стані, при гострому емоційному збудженні, відволіканні уваги від контролю руху;

2) поверховість працівників сервісних центрів МВC під час перевірки професійних знань та вмінь 
осіб, які прагнуть отримати право на керування транспортом, корисливі зловживання при виконанні цих функцій та відповідних операцій;

3) невикористання водієм і пасажирами пристосувань індивідуальної безпеки;

4) порушення нормативів робочого часу, що викликає психологічне перенапруження водія;

5) віктимна поведінка пасажирів;

6) конструктивні недоліки автотранспортних засобів, особливо системного керування та гальмування;

7) неналежний контроль власників за технічним станом автотранспортних засобів;

8) недостатнє фінансування дорожнього господарства, що перешкоджає підтриманню в належному стані автомобільних шляхів і доріг, дотриманню нормативів їх прокладення, утримання, ремонту [3, с. 691-692].

Інший вітчизняний учений B. А. Мисливий додатково виділяє такі чинники, що детермінують вчинення порушення правил безпеки дорожнього руху або експлуатації транспорту:

1) організаційні недоліки в діяльності суб'єктів експлуатації транспорту, які належним чином не виконують вимог законодавства про дорожній рух, програм і нормативних документів Кабінету Міністрів України;

2) неналежна організація нагляду та контролю дорожнього руху, передусім територіальними підрозділами Національної поліції (патрульної поліції);

3) невідповідність технічних параметрів та несправність транспортного засобу;
4) погодні умови та непристосованість шляхів до їх ускладнення;

5) нестабільність та суперечливість нормативно-правового регулювання дорожнього руху, у тому числі організації діяльності поліції [4, c. 215].

Утім, як свідчить наше дослідження, причини та умови порушень правил безпеки дорожнього руху або експлуатації транспорту залежать від самої особи, яка керує транспортним засобом, та конкретної життєвої ситуації, що виникла на момент учинення вказаного порушення.

Проте ми не поділяємо думки тих кримінологів, які вважають, що сама собою конкретна життєва ситуація на дорозі, навіть у разі вираженої складності, не може стати причиною порушень правил безпеки дорожнього руху або експлуатації транспорту.

Наша позиція грунтується на тому, що конкретна життєва ситуація має різни форми прояву. Якщо особа, яка керує транспортним засобом після весілля або святкування дня народження (а це конкретна життєва ситуація), сідає за кермо транспортного засобу в нетверезому стані, імовірність учинити порушення правил безпеки дорожнього руху набагато вища, ніж коли ця особа буде тверезою.

Інша життєва ситуація - коли особа, керуючи транспортним засобом, везе до лікарні хвору людину або вагітну жінку і при цьому порушує правила безпеки дорожнього руху, то ця особа усвідомлює таке порушення, але нехтує правилами дорожнього руху та безпеки, виражаючи при цьому особливий вид антисуспільного прояву. У цьому разі йдеться про інший ступінь вираже- 
ності порушень правил безпеки дорожнього руху.

На жаль, якщо вірити статистиці, кожні 42 хвилини одна людина стає жертвою порушень правил безпеки дорожнього руху або експлуатації транспорту, у тому числі й злочину, передбаченого статтею 286 КК України.

Водночас, за даними статистики аварійності в Україні, щороку під час дорожньо-транспортних пригод гине від 3 до 4 тис. осіб різного віку, ще близько 32 тис. одержують травми різного ступеня тяжкості.

Особливо тривожним $є$ те, що у 2016 році понад 42,6\% загиблих у дорожньо-транспортних пригодах пішоходи та велосипедисти. Ситуація з аварійністю на дорогах трагічна ще й тому, що гинуть діти. Так, за останній шестирічний період на дорогах України загинуло 1,4 тис. дітей віком до 18 років, а дорожньо-транспортні пригоди в Україні $є$ першою за поширеністю причиною смерті молоді віком від 15 до 24 років та другою за поширеністю причиною смерті дітей віком від 5 до 14 років. Тільки за 2016 рік на автошляхах України загинуло 172 дитини, минулого року 216 дітей [5].

Кількість загиблих і травмованих від цих порушень досить значна, а матеріальні збитки занадто великі, тому держава потребує від учених-кримінологів не тільки проведення грунтовного дослідження цієї проблеми, а й надання пропозицій щодо чинного законодавства та рекомендацій застосування ефективних заходів запобігання порушенням правил безпеки дорожнього руху або експлуатації транспорту особою, яка керує транспортним засобом.
Отже, змістом злочинної поведінки особи, яка керує транспортним засобом, є порушення правил безпеки дорожнього руху або експлуатації транспорту, але таке порушення повинно створити на дорозі об'єктивно небезпечну ситуацію. До речі, порушення правил безпеки дорожнього руху або експлуатації транспорту $\epsilon$ результатом не тільки небезпечної ситуації, яка складається в процесі складної взаємодії декількох учасників дорожнього руху між собою, а й життєвих ситуацій, що виникають в осіб, які керують транспортними засобами, поза межами їх злочинної поведінки.

3 цього приводу варто звернути увагу на причинно-наслідкові зв'язки та умови вчинення особами, які керують транспортними засобами, порушення правил безпеки дорожнього руху або експлуатації транспорту.

Вітчизняний учений А. П. Закалюк з цього приводу виокремлює чотири основні варіанти співвідношення сторін взаємодії (особистості та середовища) у механізмі необережного, зокрема транспортного, злочину. Перший - 3 переважанням у зумовлювальному комплексі впливу елементів середовища та значно меншою значущістю елементів особистості особи, яка вчиняє злочин. Другий - 3 приблизно рівною мірою зумовлювального впливу елементів середовища і особи. Третій - $з$ переважанням у зумовлені злочину впливу елементів, що залежать від особи та її індивідуальних якостей, та меншою мірою - елементів середовища. Четвертий - за відсутності впливу елементів середовища або неможливості визначити типове співвідношення між ними й елементами особи [3, с. 666-667]. 
Інший український учений В. А. Мисливий уважає, що саме обстановка $\epsilon$ важливим елементом кримінологічної характеристики механізму злочинної поведінки при транспортному злочині і відносить їі до системи об'єктивних і суб'єктивних чинників, які взаємодіють між собою та характеризують умови місця, часу, дорожні, метеорологічні та інші, особливості поведінки учасників події та інші обставини, що впливають на злочинну поведінку.

На підставі аналізу їі видів (проста, складна, кульмінаційна, екстремальна, фатальна тощо) автор вважає найбільш обгрунтованим використання в характеристиці механізму злочинної поведінки небезпечної та аварійної обстановки як таких, що органічно пов'язуються 3 відповідними кримінально-правовими ознаками цих злочинів.

Крім того, учений вважає, що на злочинну поведінку впливає також і взаємодія винного з потерпілим та іншими суб'єктами дорожнього руху в матеріальній та ідеальній формах, неузгодженість яких, розбіжність або невиправданість призводить до виникнення небезпечної та аварійної обстановки і настання суспільно небезпечних наслідків [7, с. 19-20].

Отже, якщо дотримуватися позиції В.А. Мисливого, то можна зробити висновок, що кримінологічна характеристика особи, яка керує транспортним засобом, при вчиненні порушень правил безпеки дорожнього руху або експлуатації транспорту здебільшого відносить цю особу до категорій так званих ситуативних та нестійких злочинців. Ця позиція підтверджується і даними Державної судової адміністрації: наприклад, осіб, засуджених за вчинення злочину, передбаченого статтею 286 КК України, у 2015 році - 2548, у тому числі за частиною першою цієї статті - 1149 (45,1\%), частиною другою 1339 (52,6\%), частиною третьою $60(2,4 \%)$ осіб. Тобто в більш ніж половині випадків злочинних дій ідеться про смерть потерпілих. Щодо 1668 (42,3 \% від тих, чиї справи розглядалися судами) осіб справи закрито, у тому числі щодо 1092 $(27,7 \%)$ - у зв'язку з примиренням винного з потерпілим.

Серед засуджених у 2015 році суттєво переважають чоловіки 2423 (95,1 \%) особи. Жінок, засуджених за статтею 286 КК України, - лише 125 (4,9\%) осіб, що обумовлено як меншою їх кількістю серед водіїв, так і більшою обережністю за кермом. Скоїли злочин у стані алкогольного сп'яніння 570 (22,4\%) осіб, що свідчить про велику роль алкоголю як чинника, що призводить до злочинної поведінки.

Віковий склад засуджених на момент учинення злочину є таким: від 14 до 16 років - одна $(0,04 \%)$ особа, від 16 до 18 років - 22 (0,9\%) особи, від 18 до 25 років - 454 $(17,8 \%)$, від 25 до 30 років - 421 $(16,5 \%)$, від 30 до 50 років - 1210 (47,5\%), від 50 до 65 років - 365 (14,3\%), понад 65 років - 75 (2,9\%).

Заняття засуджених на момент учинення злочину $є$ такими: робітники - 623 особи $(24,5 \%)$, державні та інші службовці - 70 (2,7\%), приватні підприємці - 131 (5,1\%), працівники господарських товариств 103 (4,0 \%), пенсіонери, у тому числі інваліди, - 205 (8,0\%), безробітні 59 (2,3 \%). Працездатних, які не працювали і не навчалися, - 1173 особи (46,0 \%), із них 90 (3,5\%) осіб мають 
незняту і непогашену судимість. Таким чином, великий відсоток незайнятих осіб (з поправкою на кількість офіційно не зареєстрованих працівників) свідчить про ймовірні ознаки асоціальності в поведінці цих злочинців.

Освіченість осіб на час учинення злочину можна охарактеризувати так: мали повну вищу 526 (20,6 \%) осіб, базову вищу - 120 (4,7\%), професійно-технічну - 669 (26,3%), повну загальну середню - 969 (38,0 \%), базову загальну середню - 245 (9,6\%), початкову загальну - 14 $(0,5 \%)$, не мали жодної освіти - 5 $(0,2$ \%). Загалом, показники освіти суттєво не відрізняються від тих, що має інше населення, ураховуючи віковий склад засуджених. Хоча слід відзначити переважно низьку професійну кваліфікацію засуджених. Oсіб, що раніше вчиняли злочини, включно з тими, що мають незняту і непогашену судимість (кримінологічний рецидив), - 292 (11,5%) [8].

Вивчаючи поняття та зміст порушень правил безпеки дорожнього руху або експлуатації транспорту, ми звернули увагу i на моральнопсихологічну характеристику осіб, які керують транспортними засобами, і дійшли висновку, що цим особам притаманний егоїзм, соціальна безвідповідальність, нехтування правилами суспільної поведінки та викривлена оцінка наслідків порушень безпеки дорожнього руху.

I хоча в Україні сьогодні, на нашу думку, захмарні суми штрафів, кількість осіб, які керують транспортними засобами у стані сп'яніння, не зменшується, а навпаки - залишається найвищою серед інших європейських країн. Причиною такої ситуації може бути не тільки загальна висока ураженість населення традицією вживання алкоголю, а й недостатній контроль органів поліції за безпекою дорожнього руху та високий рівень корупції у цій сфері.

Негативні тенденції щодо збільшення кількості дорожньотранспортних пригод визначаються й тим, що за останні 10 років у країні істотно змінився парк автотранспортних засобів. У 2016 році середня кількість автомобілів на тисячу українців вперше перевищила 200 одиниць. Нині на тисячу українців припадає 202 автомобілі. За оцінками фахівців, процес автомобілізації триватиме і надалі. Через кілька років на 1 тис. жителів буде припадати 300-400 транспортних засобів. Таке зростання може спричинити збільшення чисельності ДТП, а отже, тенденція до підвищення тяжкості наслідків дорожньо-транспортної злочинності також зберігатиметься.

На сьогодні автомобільна транспортна система України налічує понад 9,2 млн транспортних засобів, серед яких - 6,9 млн легкових автомобілів, 250 тис. автобусів; 1,3 млн вантажних автомобілів [9]. Для порівняння відзначимо, що в США цей показник становить 200 млн одиниць.

Але все одно першопричини, на думку вітчизняного вченого Я. Д. Холмянського, належним чином не вивчаються, а тому й запобіжні заходи не можуть бути ефективними чи взагалі не застосовуються [3, c. 37].

Головним суб'єктом запобігання вчиненню порушень правил безпеки дорожнього руху або експлуатації транспорту в Україні $є$ Національна поліція України. Згідно із Зако- 
ном України «Про дорожній рух» (стаття $52^{3}$ ) до повноважень Національної поліції у сфері забезпечення безпеки дорожнього руху, зокрема, належать:

1) участь у реалізації в межах своїх повноважень державної політики у цій сфері;

2) забезпечення безпеки дорожнього руху;

3) організація супроводження i забезпечення безпечного руху транспортних засобів спеціального призначення;

4) погодження проектів на будівництво, реконструкцію і ремонт автомобільних доріг, залізничних переїздів, комплексів дорожнього сервісу та інших споруд у межах відведення автомобільних доріг;

5) погодження пропозицій стосовно обладнання засобами організації дорожнього руху місць виконання дорожніх робіт, проектів та схем організації дорожнього руху, маршрутів руху пасажирського транспорту і т. п.;

6) інформування учасників дорожнього руху про фіксацію фактів правопорушень в автоматичному режимі [10].

Закон України «Про Національну поліцію» (стаття 23) відносить до повноважень поліції відповідно до покладених на неї завдань також регулювання дорожнього руху та здійснення контролю за дотриманням ПДР його учасниками та за правомірністю експлуатації транспортних засобів на вулично-дорожній мережі [11].

Позитивною стороною встановлення причин і умов порушення правил безпеки дорожнього руху або експлуатації транспорту $є$ висновок фахівців, які проводять автотехнічну експертизу. Саме в цьому, як вважає професор I. Г. Богатирьов, полягає специфіка цих кримінальних проваджень [1, с. 104]. Іншими словами, проведення фахової автотехнічної експертизи дозволить органам поліції, які виїхали на місце вчинення порушення правил безпеки дорожнього руху або експлуатації транспорту, з'ясувати, що стало причиною такого порушення та встановити винних у їх учиненні.

Висновки. Вивчивши поняття та зміст порушень правил безпеки дорожнього руху або експлуатації транспорту особами, які керують транспортними засобами, можна зробити такі висновки:

- по-перше, нами сформульовано авторське визначення порушень правил безпеки дорожнього руху або експлуатації транспорту особами, які керують транспортними засобами: це - суспільно небезпечне шкідливе діяння особи, яка керує транспортним засобом та вчиняє шляхом дії або бездіяльності правопорушення, що передбачає адміністративну або кримінальну відповідальність;

- по-друге, оновленій структурі органів Національної поліції надано більше повноважень щодо запобігання порушенням правил безпеки дорожнього руху або експлуатації транспорту особами, які керують транспортними засобами, що відкриває нові можливості для їх ефективної роботи у сфері безпеки дорожнього руху або експлуатації транспорту;

- по-третє, вивчення порушень правил безпеки дорожнього руху або експлуатації транспорту особами, які керують транспортними засобами, потребує вироблення нових грунто- 
вних кримінально-правових та кримінологічних підходів до дослідження окресленої проблеми та є основою для формування системного підходу в профілактичній роботі та реалізації поставлених перед Національною поліцією завдань щодо відчутного зниження рівня порушень правил безпеки дорожнього руху й експлуатації транспорту особами, які керують транспортними засобами.

\section{Список використаних джерел}

1. Богатирьов I. Г. Кримінологічна характеристика та запобігання злочину, передбаченого ст. 286 КК України. Актуальні проблеми вітчизняної юриспруденції. Спец. випуск. 2019. С. 103-108.

2. Полтава К. О. Специфіка детермінації автотранспортної злочинності. Право і суспільство. 2012. № 6. С. 183-187.

3. Холмянський Я. Д. Наукова концепція правового забезпечення підвищення рівня дорожнього руху в Україні в контексті світових тенденцій боротьби зі смертельними наслідками ДТП. Вісник Донецького університету. Серія В: Економіка і право. 2007. Вип. 1. С. 35-42.

4. Закалюк А. П. Курс сучасної української кримінології: теорія і практика: У 3 кн. Київ : Видавничий Дім «Ін Юре», 2007. Кн. 2: Кримінологічна характеристика та запобігання вчиненню окремих видів злочинів. 712 с.

5. Мисливий В.А. Злочини проти безпеки дорожнього руху та експлуатації транспорту : монографія. МВС України. Юрид. акад. Дніпро, 2004. 380 с.

6. Статистика ДТП в Украине за 8 месяцев 2017 года страховщиков не радует. URL: https://forinsurer.com/news/17/10/18/35590 (дата звернення: 13.07. 2019).

7. Статистичні дані по галузі автомобільного транспорту. Міністерство інфраструктури України. URL: https://mtu.gov.ua/content/statistichni-dani-po-galuziavtomobilnogo-transportu.html?PrintVersion (дата звернення: 13.07.2019).

8. Мисливий В.А. Злочини проти безпеки дорожнього руху та експлуатації транспорту (кримінально-правове та кримінологічне дослідження) : автореф. дис. ... докт. юрид. наук. Київ, 2005. 41 с.

9. Судова влада України. Офіційний веб-потал. Розділ: Державна судова адміністрація України. Головна. Судова статистика. Форма 6. Звіт про кількість осіб, засуджених, виправданих, справи щодо яких закрито, неосудних, до яких застосовано примусові заходи медичного характеру та види кримінального покарання. Форма 7. Звіт про склад засуджених. URL: court.gov.ua/sudova_statystyka_Zvit_2015/ (дата звернення: 22.07. 2019).

10. Про дорожній рух: Закон України від 30 червня 1993 р. № 3353-XII. URL: zakon3.rada.gov.ua/ laws/show/3353-12/page (дата звернення: 21.07. 2019).

11. Про Національну поліцію: Закон України від 02 липня 2015 р. № 580-VIII. URL: http:// zakon2.rada.gov.ua/ laws/show/580-19/page (дата звернення: 15.07. 2019).

\section{References}

1. Bogatirov, I. G. (2019). Kriminologichna harakteristika ta zapobigannya zlochinu, peredbachenogo st. 286 KK Ukrayini. Aktualni problemi vitchiznyanoyi yurisprudenciyi. Spec. vipusk, 103-108 [in Ukrainian].

2. Poltava, K. O. (2012). Specifika determinaciyi avtotransportnoyi zlochinnosti. Pravo i suspilstvo, 6, 183-187 [in Ukrainian].

3. Holmyanskij, Ya. D. (2007). Naukova koncepciya pravovogo zabezpechennya pidvishennya rivnya dorozhnogo ruhu v Ukrayini v konteksti svitovih tendencij borotbi zi 
smertelnimi naslidkami DTP. Visnik Doneckogo universitetu. Seriya V: Ekonomika i pravo, 1, 35-42 [in Ukrainian].

4. Zakalyuk, A. P. (2007). Kurs suchasnoyi ukrayinskoyi kriminologiyi: teoriya i praktika: U 3 kn. Kiyiv: Vidavnichij Dim «In Yure». Kn. 2: Kriminologichna harakteristika ta zapobigannya vchinennyu okremih vidiv zlochiniv [in Ukrainian].

5. Mislivij, V. A. (2004). Zlochini proti bezpeki dorozhnogo ruhu ta ekspluataciyi transportu: monografiya. MVS Ukrayini. Yurid. akad. Dnipro [in Ukrainian].

6. Statistika DTP v Ukraine za 8 mesyacev 2017 goda strahovshikov ne raduet. URL: https://forinsurer.com/news/17/10/18/35590 (accessed: 13.07. 2019) [in Russian].

7. Statistichni dani po galuzi avtomobilnogo transportu. Ministerstvo infrastrukturi Ukrayini. URL: https://mtu.gov.ua/content/statistichni-dani-po-galuzi-avtomobilnogotransportu.html?PrintVersion (accessed: 13.07. 2019) [in Ukrainian].

8. Mislivij, V.A. (2005). Zlochini proti bezpeki dorozhnogo ruhu ta ekspluataciyi transportu (kriminalno-pravove ta kriminologichne doslidzhennya). (Avtoref. dis. ... dokt. yurid. nauk). Kiyiv [in Ukrainian].

9. Sudova vlada Ukrayini. Oficijnij veb-potal. Rozdil: Derzhavna sudova administraciya Ukrayini. Golovna. Sudova statistika. Forma 6. Zvit pro kilkist osib, zasudzhenih, vipravdanih, spravi shodo yakih zakrito, neosudnih, do yakih zastosovano primusovi zahodi medichnogo harakteru ta vidi kriminalnogo pokarannya. Forma 7. Zvit pro sklad zasudzhenih. URL: court.gov.ua/sudova_statystyka_Zvit_2015/ (accessed: 22.07. 2019) [in Ukrainian].

10. Pro dorozhnij ruh: Zakon Ukrayini vid 30 chervnya 1993 r. № 3353-XII. URL: zakon3.rada.gov.ua/ laws/show/3353-12/page (accessed: 21.07. 2019) [in Ukrainian].

11. Pro Nacionalnu policiyu: Zakon Ukrayini vid 02 lipnya 2015 r. № 580-VIII. URL: http:// zakon2.rada.gov.ua/ laws/show/580-19/page (accessed: 15.07. 2019) [in Ukrainian].

V. Khelik, Postgraduate Student of the Security, Law Enforcement and AntiCorruption Activity Chair of the Interregional Academy of Personnel Management

\section{Concept and content of violations of safety rules of traffic by persons steering vehicles}

In article the concept and content of traffic violations by the persons steering vehicles is opened. It is found out that prevention of traffic violations by the persons steering vehicles is a current criminological problem. It is proved that the legislation in this sphere is not perfect. Author's definition of offense of safety rules of traffic or operation of transport by the persons steering vehicles is formulated - this socially dangerous harmful act of the person, which steers the vehicle and commits offense, which provides administrative or criminal liability by action or inaction. In the updated structure of bodies of National police, it is offered to confer more powers on prevention of violations of safety rules of traffic from persons who steer vehicles that opens new opportunities for their effective work in the sphere of traffic safety or operation of transport.

Studying of offenses of safety rules of traffic or operation of transport by the persons steering vehicles showed the need for elaboration of new fundamental criminal and criminological approaches to a research of the designated problem. 
The attention to relationships of cause and effect and conditions of commission of offenses of safety rules of traffic or operation of transport by persons, which steer vehicles, is paid. Therefore, offense of safety rules of traffic or operation of transport is result not only creations of a dangerous situation which arises in the course of difficult interaction of several participants of traffic among themselves, and life situations which arise at the persons steering vehicles outside their criminal behavior.

It is proved that a basis for notable decrease in level of offenses of safety rules of traffic or operation of transport by the persons steering vehicles is elaboration of system approach by National police in scheduled maintenance with breakers of rules of traffic.

Keywords: violations; rules; traffic; operation; person.

Надійшла до редакції 01.08.2019 